\title{
Effect of Heavy Metal Present in Cement Dust on Soil and Plants of Nokha (Bikaner)
}

\author{
SURUCHI GUPTA and SARIKA SHARMA
}

Research Laboratory, Government Dungar College Bikaner, India.

http://dx.doi.org/10.12944/CWE.8.2.16

(Received: June 20, 2013; Accepted: August 25, 2013)

\begin{abstract}
In Nokha(Bikaner) cement industries emittes cement dust in nearby farmers fields. In these industries cement dust emitted contains traces of hexavalent chromium and lead well above permissible limit in area under investigation. However, cadmium and nickel were found below limits prescribed. To analyse heavy metals viz, $\mathrm{Cr}^{+6}$, lead, Cadmium and nickel one hundred and twenty samples were collected from four directions on surface and $20 \mathrm{~cm}$ depth, and analyzed on atomic absorption spectrophotometer. From the above study it is clear that in case of Sarvottam cement works only lead content was higher in all directions and depths than other two plants. At tiger and Nokha cement works contamination of lead was more over limited in the first $1 \mathrm{~km}$ except in east direction. Mobility of lead was relatively more on top soil than $20 \mathrm{~cm}$ depth. Hexavalent chromium content in south western direction was more for Nokha cement. Whereas, it was more in east direction in case of tiger cement. This indicated influence of prevailing direction of wind on distribution of heavy metals present in cement dust. Heavy metal toxicity results in reduction in plant height, burning of leaf margins and tip, slow leaf growth and over all wilting of Prosopis cineraria, Pearlmillet and clusterbean plants, when this metal deposits in Human body results in genetic disorders. Electrostatic precipitator can be installed to reduce the cement dust emission.
\end{abstract}

Key words : Cement dust, Hexavalent Chromium, Lead, Cadmium, Nickel, Toxicity .

\section{INTRODUCTION}

Complex electronic chemistry of heavy metals viz. $\mathrm{Cr}^{+6}, \mathrm{~Pb}, \mathrm{Cd}$ and $\mathrm{Ni}$ have been a major hurdle in unraveling its toxicity mechanism in soil and plants ${ }^{1}$. Heavy metal toxicity in plants is observed at multiple levels from reduced yield, through effects on leaf and root growth, to inhibition an enzymatic activities and mutagenesis. The area under present investigation is a large industrial area with two cement plants running for a very long time along the roadside on $\mathrm{NH} 89$.

\section{EXPERIMENTAL}

\section{Study Area}

Nokha is located within the arid western desert region of Rajasthan at a distance of $63 \mathrm{~km}$ from the city of Bikaner. Its temperature varies from 48 degree in summer to 1 degree in winter with annual rainfall of about $298 \mathrm{~mm}$. To study the effect of cement dust, whole area around three cement plants namely; Sarvottam, Tiger cement and Nokha cement were studied. the Sarvottam cement plant which is located at the distance of $5 \mathrm{~km}$ from Nokha (Bikaner) on national highway number 89 near Charkhada village; Tiger and Nokha cement are located in RIICO industrial, Nokha area at a distance of $500 \mathrm{~m}$ from each other.

\section{Sampling and Procedure}

Study area around the plants was divided into four radiant directions of east, south, west and north in clockwise manner ${ }^{2,3}$. Soil samples were taken at surface and $20 \mathrm{~cm}$ depth at $100 \mathrm{~m}, 500 \mathrm{~m}, 1$ $\mathrm{km}, 2 \mathrm{~km}$ and $3 \mathrm{~km}$ distances(10 samples each) in plastic bags of $1 / 2 \mathrm{~kg}$ each. Prior to analysis, the samples were cleaned using wire mesh and pebbles removed. The samples were filtered using Whatman no.42 filter paper. $\mathrm{Cr}^{+6}, \mathrm{~Pb}, \mathrm{Cd}$ and $\mathrm{Ni}$ was determined by atomic absorption spectrophotometer (nov AA 400) in flame mode as given by Perkin Elmer. ${ }^{4}$ 


\section{RESULTS AND DISCUSSION}

The present study was carried out to study effect of heavy metal present in cement dust on soil and plant during 2009-2010. As per central pollution control board standards of (1995), chromium(0.1 ppm), $\mathrm{Pb}(0.1 \mathrm{ppm}), \mathrm{Cd}(2 \mathrm{ppm})$ and $\mathrm{Ni}(3 \mathrm{ppm})$ is toxic for agricultural operations and industry ${ }^{5}$. A perusal of table1, 2, 3 and 4 revealed following results:

\section{East Direction \\ Sarvottam Cement}

Lead content ranged between 0.650 to $0.112 \mathrm{ppm}$ upto $500 \mathrm{~m}$ distance all of them above limit after that it declined below limit. Hexavalent chromium, cadmium and nickel content was lower at all the distances.

\section{Tiger Cement}

Lead content ranged higher between 0.699 to $0.139 \mathrm{ppm}$ upto $1 \mathrm{~km}$. Hexavalent chromium also ranged higher between $0.199 \mathrm{ppm}$ to $0.108 \mathrm{ppm}$ upto $500 \mathrm{~m}$. However, cadmium and nickel content was relatively much less compared to other two plants.

\section{Nokha Cement}

Lead content ranged higher between 0.515 to $0.118 \mathrm{ppm}$ upto $500 \mathrm{~m}$ distance only. Hexavalent chromium also was higher in the first $100 \mathrm{~m}$ ranged between $0.129 \mathrm{ppm}$ to $0.103 \mathrm{ppm}$, however at all other sites it was below limits. Interestingly, cadmium and nickel content was lower at all the distances both at surface and $20 \mathrm{~cm}$ soil depths.

\section{South Direction \\ Sarvottam Cement}

Lead content ranged higher between 0.708 to $0.114 \mathrm{ppm}$ upto $1 \mathrm{~km}$ distance. Hexavalent chromium, cadmium and nickel content was lower at all the distances.

\section{Tiger Cement}

Lead content ranged between 0.511 to $0.119 \mathrm{ppm}$ all of them were above limit upto $1 \mathrm{~km}$ distance more so on surface soil than at $20 \mathrm{~cm}$ depth. Hexavalent chromium ranged between 0.155 to
$0.118 \mathrm{ppm}$ upto $500 \mathrm{~m}$ distance, however, showed decline after that. Cadmium and nickel content was lower at all the distances.

\section{Nokha Cement}

Lead content ranged higher between 0.441 to $0.203 \mathrm{ppm}$ upto $2 \mathrm{~km}$ more so on surface soil than at $20 \mathrm{~cm}$ depth. Higher hexavalent chromium ranged between 0.173 to $0.116 \mathrm{ppm}$ upto $500 \mathrm{~m}$ distance, however, showed decline after that. Cadmium and nickel content was lower at all the distances.

\section{West Direction \\ Sarvottam Cement}

Lead content ranged higher between 0.590 to $0.138 \mathrm{ppm}$ upto $2 \mathrm{~km}$. Hexavalent chromium, cadmium and nickel content were lower at all the distances.

\section{Tiger Cement}

Lead content was higher ranged between 0.560 to $0.175 \mathrm{ppm}$ upto $1 \mathrm{~km}$ distance. Hexavalent chromium ranged between $0.173-0.105$ ppm higher above limits upto $2 \mathrm{~km}$ distance. Cadmium and nickel content were lower than prescribed limits.

\section{Nokha Cement}

Lead content ranged between 0.427 to $0.137 \mathrm{ppm}$ all of than above limit upto $2 \mathrm{~km}$ distance. Hexavalent chromium ranged between 0.136 $0.104 \mathrm{ppm}$ higher above limits upto $1 \mathrm{~km}$ distance surface soil. Cadmium and nickel content were lower than prescribed limits at all sites.

\section{North Direction \\ Sarvottam Cement \\ Lead content ranged higher between} 0.567 to $0.154 \mathrm{ppm}$ all of them above limit upto 1 $\mathrm{km}$. Hexavalent chromium, cadmium and nickel content was lower at all the distances

\section{Tiger Cement}

Lead content was above limits ranged between 0.178 to $0.107 \mathrm{ppm}$ upto $500 \mathrm{~m}$. Hexavalent chromium ranged between 0.162-0.119 generally higher upto $500 \mathrm{~m}$. Cadmium and nickel content was lower at all the distances 

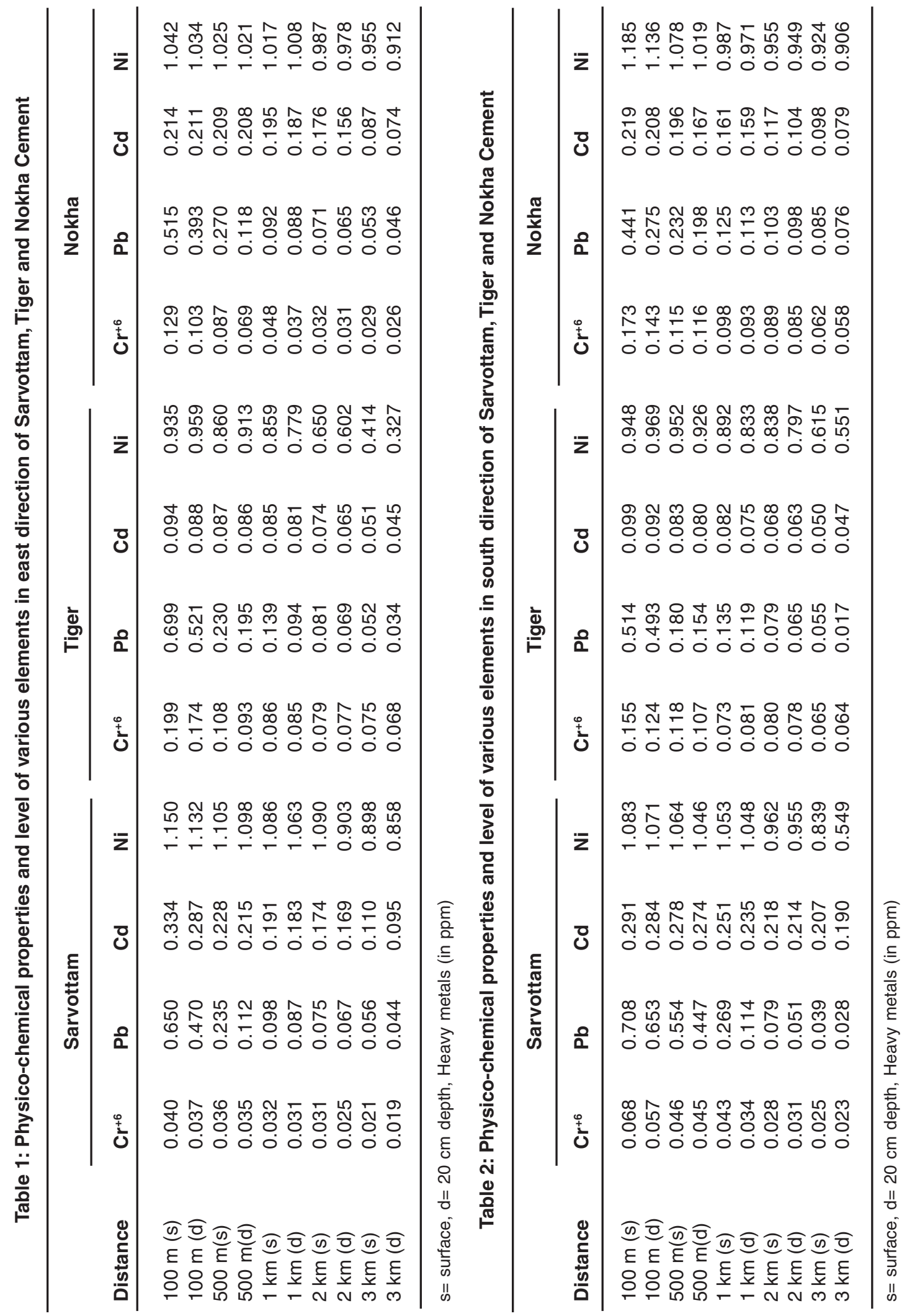

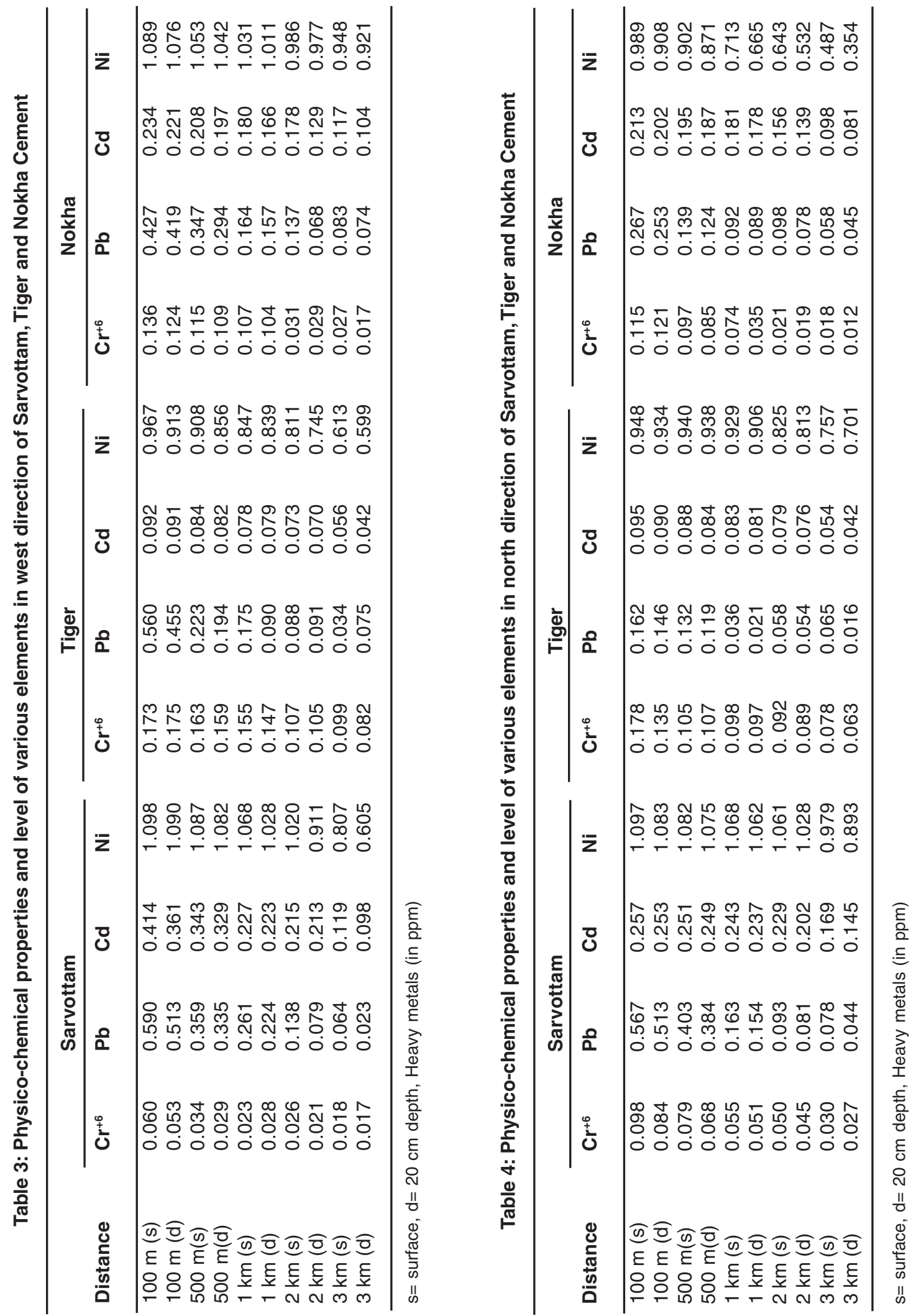


\section{Nokha Cement}

Lead ranged between 0.267-0.123 ppm generally higher upto 500m distance after that it gradually declined. Hexavalent chromium was higher in the first 100m distance ranged between 0.115-0.121 ppm, however, at rest of the sites it was below limits. Cadmium and nickel content was lower at all the distances

\section{CONCLUSION}

This is clear from the above study that in case of Sarvottam cement works only lead content was higher in all directions and depth than other two plants. At tiger and Nokha cement works contamination of lead was more over limited in the first $1 \mathrm{~km}$ except in east direction. Mobility of lead was relatively more on top soil than $20 \mathrm{~cm}$ depth. Hexavalent chromium content in south western direction was more for both Tiger and Nokha cement. This indicated influence of prevailing direction of wind on distribution of heavy metals present in cement dust ${ }^{6}$.

It is concluded from the present investigation that if cement dust with traces of heavy metals continues to fall on soil and plants, it will affect the yield of plants and reduction in fertility of soil. Higher concentration of heavy metals leads to stunted growth, leaf necrosis, decrease in root growth and reduced activities of various enzymes leading to less flowering and seed setting in plants effected. The accumulation of heavy metals in Prosopis cineraria, pearlmillet and clusterbean plant parts which when used by humans will also brings diseases in them viz. changes in gastro intestinal tract as well as in accumulation in liver, kidneys, thyroid gland and bone marrow. The various hexavalent chromium compounds represent the major risk especially due to genetic effect. Keeping above analysis in mind, it is strongly recommended to emit cement dust after treatment with electrostatic precipitator.

\section{REFERENCES}

1. Shanker, A. K. and Carlos Cervantes. Environ int., 31: 739 (2005)

2. Gupta, S. and Solanki, A. Int. J. Chem. Sci. 6(2): 681- 687(2008).

3. Ibanga, I.J., Umoh, N.B. and Iren, O.B. Soil analysis and plant analysis. 39(3\&4): 552 (2008).

4. Isaac, R.A. and Kerber, J.D. Soil science society of America, Madison W.I. (1971)
5. Gupta, P. K. Methods in environmental analysis: water, soil and air. Agrobios (India), Jodhpur, p 18-19 (2000).

6. Zerrouqui, Z., Sbaa, M., Qujidi, M., Elkharmouz, M., Bengamra, S. and Zerrouqi, A. Assessment of cement's dust impact on the soil using principal component analysis and GIS. Int. J. Environ. Sci. Tech., 5(1):125134. ISSN: 1735-1472. (Winter,2008) 